\title{
Yield and Quality of Intercropped Sunflower with Soybean Under Different Sunflower Plant Spacings and Slow - Release Nitrogen Fertilizer Rates in Sandy Soil
}

\author{
Sherif Ibrahim Abdel-Wahab ${ }^{1}$, Amal Mahmoud El Manzlawy \\ ${ }^{1}$ Crop Intensification Research Department, Field Crops Research Institute, Agricultural Research Center, Giza, Egypt \\ ${ }^{2}$ Seed Technology Research Department, Field Crops Research Institute, Agricultural Research Center, Giza, Egypt
}

Email address:

twins00twins50@yahoo.com

\section{To cite this article:}

Sherif Ibrahim Abdel-Wahab, Amal Mahmoud El Manzlawy. Yield and Quality of Intercropped Sunflower with Soybean Under Different Sunflower Plant Spacings and Slow - Release Nitrogen Fertilizer Rates in Sandy Soil. International Journal of Applied Agricultural Sciences. Vol. 2, No. 3, 2016 pp. 32-43. doi: 10.11648/j.ijaas.20160203.11

Received: March 30, 2016; Accepted: April 6, 2016; Published: May 17, 2016

\begin{abstract}
A two - year field trial was conducted in El-Boustan region, South El-Tahrir Province, El-Behira Governorate, Egypt to decrease mineral nitrogen $(\mathrm{N})$ inputs of sunflower and increase yield and quality of the intercrops to achieve farmer's benefit under sandy soil conditions. A split-plot design with three replicates was used. Quality of sunflower and soybean seeds was tested in the laboratories of Seed Technology Research Department, Field Crops Research Institute, Agricultural Research Center. For soybean crop, average yield of soybean with sunflower was greater by intercropping soybean with sunflower that spaced at $40 \mathrm{~cm}$ in the same ridge. Slow - release $\mathrm{N}$ fertilizer rates of sunflower did not affect all the studied soybean traits. Also, soybean yield and its attributes were not affected by the interaction between sunflower plant spacing and slow - release $\mathrm{N}$ fertilizer rates of sunflower. Seed oil content of soybean was increased by increasing sunflower plant spacing from 20 to 40 $\mathrm{cm}$, meanwhile quality of soybean seeds was not affected by slow - release $\mathrm{N}$ fertilizer rates of sunflower or the interaction between sunflower plant spacing and slow - release $\mathrm{N}$ fertilizer rates of sunflower. For sunflower crop, intercropping soybean with sunflower that spaced at $20 \mathrm{~cm}$ had the highest seed and oil yields per ha compared to the others. All the studied sunflower traits were increased by increasing $\mathrm{N}$ fertilizer rates of sunflower from 71.4 to $142.8 \mathrm{~kg} \mathrm{~N} / \mathrm{ha}$ except number of leaves per plant. The interaction between sunflower plant spacing and slow - release $\mathrm{N}$ fertilizer rates of sunflower affected significantly all the studied sunflower traits except number of leaves per plant. Quality of sunflower seeds was not affected significantly by sunflower plant spacing but it was increased by increasing $\mathrm{N}$ fertilizer rates of sunflower from 71.4 to $142.8 \mathrm{~kg}$ $\mathrm{N} / \mathrm{ha}$. The interaction between sunflower plant spacing and slow - release $\mathrm{N}$ fertilizer rates of sunflower did not affect quality of sunflower seeds. Land equivalent ratio values for intercrops were much greater than 1.00 indicating less land requirements of intercropping systems than sole sunflower. Farmer's benefit was achieved by intercropping soybean with sunflower plants that spaced at $20 \mathrm{~cm}$ between hills $(50 \%$ soybean $+100 \%$ sunflower) and received $75 \%$ of the recommended mineral $\mathrm{N}$ fertilizer rate of sunflower under sandy soil conditions.
\end{abstract}

Keywords: Intercropping, Sunflower Plant Spacing, Soybean, Slow - Release Nitrogen, Yield Quality, Farmer's Benefit

\section{Introduction}

Sunflower (Helianthus annuus L.) is widely adaptable and more drought tolerant than most other grain crops [1] and hence it is one of the most important oil crops in the world [2]. However, the production of edible oil in Egypt is still far below the needs and the country has to supplement the needs for oil to meet the annual requirements by importing. The requirements of edible oil are not likely to increase with rapidly growing population. Therefore, there is a big problem concerning edible oil production where the local oil production satisfies $13 \%$ only of the total requirement [3]. Great emphasis must be given towards oil seed crops to decrease the oil gap in Egypt outside the Nile Valley and Delta without soil degradation and pollution where nitrogen (N) requires careful management when used for crop 
production on sandy soils. Consequently, newly reclaimed soils in Egypt offer a great opportunity to increase the area devoted to oil seed crops by the proper choice of cropping system with the optimum use of mineral $\mathrm{N}$ fertilizer because of the high potential for leaching losses of nitrate through these soils. Sunflower ranks with soybean (Glycine max L), canola (Brassica napus L.) and peanut (Arachis hypogaea L.) as one of the four most important annual crops in the world grown for edible oil [4].

Accordingly, it is important to address our efforts to this fundamental issue by increasing edible oil production per unit area by intercropping soybean with sunflower without excessive use of mineral $\mathrm{N}$ fertilizer under sandy soil conditions. Yield components of sunflower can be governed by plant density and distribution of these plants per unit area with regard to soybean cultivar and its plant density as the competition for environmental resources between them must be less than exists within the same species [5] under sandy soil conditions. Thereby, intercropping can provide production advantages over sole crops in the absence of increased external inputs due to more efficient utilization of resources [6]. Sunflower and soybean are two species that can be intercropped [7]. In this concern, Andrade et al. [8] reported that sunflower-soybean intercrop has emerged as an option that increases land productivity compared with sole crops because of complementary use of resources between species. Consequently, intercropped sunflower and soybean complement each other in the use of resources because critical periods for yield determination occur at different times during a period of low resource demand by the other component [9].

. On the other hand, stand density may affect seed yield of both crops under sandy soil conditions, especially there was a significant correlation between plant population and oil content of sunflower [10]. Plant densities, planting patterns and plant densities $\times$ planting pattern had a significant effect on sunflower yield [11]. Also, both population density and intercropping decreased significantly soybean seed oil content [12]. The local soybean cultivar Giza 22 was more compatible for intercropping under sandy soil conditions [13] Moreover, great efforts have been made by Egyptian scientists to improve sunflower productivity by increasing the efficiency of mineral $\mathrm{N}$ fertilizer application by controlling the release or minimizing loss of $\mathrm{N}$ nutrient. It is known that slow-release $\mathrm{N}$ fertilizers are excellent alternative to soluble fertilizer. Nutrients are released at a slower rate throughout the season and the plants are able to absorption most of the nutrients without waste by leaching under sandy soil conditions. Excessive $\mathrm{N}$ fertilization of sunflower not only generates that environmental risk, it may also affect the grain quality, decreasing its oil content and reduce yield through an increase of plant lodging [14]. N plays a critical role in producing unsaturated fatty acids (oleic and linoleic acids), which are the main factors determining sunflower oil quality [15]. Certainly, an increase in mineral $\mathrm{N}$ fertilizer increased the seed yield of sunflower but reduced the seed oil content [16]. Accordingly, the economic optimum rate of mineral $\mathrm{N}$ fertilizer for each intercrop under sandy soil conditions is a crucial factor to maximize land use. Therefore, the main objective of the present research was to decrease mineral $\mathrm{N}$ inputs of sunflower and increase yield and quality of the intercrops to achieve farmer's benefit under sandy soil conditions.

\section{Material and Methods}

A two- year study was carried out at El-Boustan region, South El-Tahrir Province, El-Behira Governorate (Lat. 30 $30^{\prime} 14^{\prime \prime} \mathrm{N}$, Long. $30^{\circ} 19$ 11" E, $21 \mathrm{~m}$ a.s.1.), Egypt during 2014 and 2015 seasons. The experimental soil had $6.58 \%$ clay, $2.11 \%$ silt, and $72.09 \%$ course sand, $19.22 \%$ fine sand, and the texture was sandy. Chemical analysis of the soil $(0-$ $30 \mathrm{~cm}), \mathrm{pH}$ value, available $\mathrm{N}$, available $\mathrm{P}$ and available $\mathrm{K}$ were analyzed by Water and Soil Research Institute, ARC (Table 1). Methods of mechanical and chemical analysis employed were as described by Chapman and Pratt [17].

Table 1. Chemical properties of El-Boustan region in 2014 and 2015 seasons before growing soybean and sunflower.

\begin{tabular}{lcc}
\hline \multirow{2}{*}{ Chemical properties } & \multicolumn{2}{c}{ Growing season } \\
\cline { 2 - 4 } $\mathrm{pH}$ & $\mathbf{2 0 1 4}$ & 7.87 \\
Available N (ppm) & 22.00 & 30.00 \\
Available P (ppm) & 12.00 & 15.50 \\
Available K (ppm) & 105.00 & 120.00 \\
\hline
\end{tabular}

Wheat was the preceding winter crop in both seasons. Sprinkler irrigation was the irrigation system in this study. Irrigation for the first day (three hours/day) then skips the two successive days and so on from sowing up to harvest. Calcium super phosphate $\left(15.5 \% \mathrm{P}_{2} \mathrm{O}_{5}\right)$ at rate of $476 \mathrm{~kg}$ per ha and potassium sulfate $\left(48.0 \% \mathrm{~K}_{2} \mathrm{O}\right)$ at rate of $119 \mathrm{~kg}$ per ha were applied during soil preparation in the two summer seasons. Seeds of soybean cultivar Giza 22 were inoculated with Bradyrhizobium japonicum and Arabic gum was used as a sticking agent. Soybean seeds were sown on May $12^{\text {th }}$ and $16^{\text {th }}$ in 2014 and 2015 seasons, respectively, meanwhile seeds of sunflower cultivar Sakha 53 were sown on May $26^{\text {th }}$ and $30^{\text {th }}$ in 2014 and 2015 seasons, respectively. Mineral N fertilizer of soybean was added at rate of $47.6 \mathrm{~kg} \mathrm{~N} / \mathrm{ha}$ as urea ' $46.5 \% \mathrm{~N}$ " at 21 days from sowing under intercropping and sole cultures. Mineral $\mathrm{N}$ fertilizer of sole sunflower was added at rate of $142.8 \mathrm{~kg} \mathrm{~N} / \mathrm{ha}$ as urea ' $46.5 \% \mathrm{~N}$ ' divided into four equal doses which applied at sunflower sowing, 15, 30 and 45 days from sunflower sowing. Normal recommended cultural practices for growing sunflower and soybean crops were used. Soybean plants were harvested on September $11^{\text {th }}$ and $14^{\text {th }}$ in 2014 and 2015, respectively. Sunflower plants 
were harvested on September $2^{\text {nd }}$ and $4^{\text {th }}$ in 2014 and 2015, respectively.

The experiment included nine treatments which were the combination between three sunflower plant spacings (one plant/hill spaced at 20,30 and $40 \mathrm{~cm}$ were expressed as 100 , 75 and $50 \%$ of sole culture, respectively) with three mineral $\mathrm{N}$ fertilizer rates of sunflower $(142.8 \mathrm{~kg} \mathrm{~N} / \mathrm{ha}$ as urea $46.5 \%$ $\mathrm{N}^{\prime}$ without urea formaldehyde form [ $\left.\mathrm{UF}_{0}\right], 107.1 \mathrm{~kg} \mathrm{~N} / \mathrm{ha}$ as urea formaldehyde form $\left[\mathrm{UF}_{1}\right]$ and $71.4 \mathrm{~kg} \mathrm{~N} / \mathrm{ha}$ as urea formaldehyde form $\left[\mathrm{UF}_{2}\right]$ under intercropping culture.

The first mineral $\mathrm{N}$ fertilizer rate $(142.8 \mathrm{~kg} \mathrm{~N} / \mathrm{ha})$ divided into four equal doses which applied at sunflower sowing, 15, 30 and 45 days from sunflower sowing. Slow-release N fertilizer raters (107.1 and $71.4 \mathrm{~kg} \mathrm{~N} / \mathrm{ha})$ were applied at sunflower sowing. Slow-release $\mathrm{N}$ fertilizers (Enciabien 40\% $\mathrm{N})$ were obtained by General Organization for Agricultural Equalization Fund, ARC, Giza, Egypt. The treatments were shown in Figure (1) as follows:

1. Sunflower seeds were sown in both sides of ridge $(120$ $\mathrm{cm}$ width) by growing one plant/hill spaced at $20 \mathrm{~cm}$, meanwhile soybean seeds were grown in two rows in middle of the ridge (two plants/hill spaced at $20 \mathrm{~cm}$ ) that received $142.8 \mathrm{~kg} / \mathrm{ha}\left(\mathrm{UF}_{0}\right)$. This pattern was expressed as $50 \%$ soybean $+100 \%$ sunflower.

2. Sunflower seeds were sown in both sides of ridge $(120$ $\mathrm{cm}$ width) by growing one plant/hill spaced at $20 \mathrm{~cm}$, meanwhile soybean seeds were grown in two rows in middle of the ridge (two plants/hill spaced at $20 \mathrm{~cm}$ ) that received $107.1 \mathrm{~kg} / \mathrm{ha}\left(\mathrm{UF}_{1}\right)$. This pattern was expressed as $50 \%$ soybean $+100 \%$ sunflower.

3. Sunflower seeds were sown in both sides of ridge $(120$ $\mathrm{cm}$ width) by growing one plant/hill spaced at $20 \mathrm{~cm}$, meanwhile soybean seeds were grown in two rows in middle of the ridge (two plants/hill spaced at $20 \mathrm{~cm}$ ) that received $71.4 \mathrm{~kg} / \mathrm{ha}\left(\mathrm{UF}_{2}\right)$. This pattern was expressed as $50 \%$ soybean $+100 \%$ sunflower

4. Sunflower seeds were sown in both sides of ridge $(120$ $\mathrm{cm}$ width) by growing one plant/hill spaced at $30 \mathrm{~cm}$, meanwhile soybean seeds were grown in two rows in middle of the ridge (two plants/hill spaced at $20 \mathrm{~cm}$ ) that received $142.8 \mathrm{~kg} / \mathrm{ha}\left(\mathrm{UF}_{0}\right)$. This pattern was expressed as $50 \%$ soybean $+75 \%$ sunflower.

5. Sunflower seeds were sown in both sides of ridge $(120$ $\mathrm{cm}$ width) by growing one plant/hill spaced at $30 \mathrm{~cm}$, meanwhile soybean seeds were grown in two rows in middle of the ridge (two plants/hill spaced at $20 \mathrm{~cm}$ ) that received $107.1 \mathrm{~kg} / \mathrm{ha}\left(\mathrm{UF}_{1}\right)$. This pattern was expressed as $50 \%$ soybean $+75 \%$ sunflower.

6. Sunflower seeds were sown in both sides of ridge (120 $\mathrm{cm}$ width) by growing one plant/hill spaced at $30 \mathrm{~cm}$, meanwhile soybean seeds were grown in two rows in middle of the ridge (two plants/hill spaced at $20 \mathrm{~cm}$ ) that received $71.4 \mathrm{~kg} / \mathrm{ha}\left(\mathrm{UF}_{2}\right)$. This pattern was expressed as $50 \%$ soybean $+75 \%$ sunflower

7. Sunflower seeds were sown in both sides of ridge (120 $\mathrm{cm}$ width) by growing one plant/hill spaced at $40 \mathrm{~cm}$, meanwhile soybean seeds were grown in two rows in middle of the ridge (two plants/hill spaced at $20 \mathrm{~cm}$ ) that received $142.8 \mathrm{~kg} / \mathrm{ha}\left(\mathrm{UF}_{0}\right)$. This pattern was expressed as $50 \%$ soybean $+50 \%$ sunflower.

8. Sunflower seeds were sown in both sides of ridge (120 $\mathrm{cm}$ width) by growing one plant/hill spaced at $40 \mathrm{~cm}$, meanwhile soybean seeds were grown in two rows in middle of the ridge (two plants/hill spaced at $20 \mathrm{~cm}$ ) that received $107.1 \mathrm{~kg} / \mathrm{ha}\left(\mathrm{UF}_{1}\right)$. This pattern was expressed as $50 \%$ soybean $+50 \%$ sunflower.

9. Sunflower seeds were sown in both sides of ridge ( 120 $\mathrm{cm}$ width) by growing one plant/hill spaced at $40 \mathrm{~cm}$, meanwhile soybean seeds were grown in two rows in middle of the ridge (two plants/hill spaced at $20 \mathrm{~cm}$ ) that received $71.4 \mathrm{~kg} / \mathrm{ha}\left(\mathrm{UF}_{2}\right)$. This pattern was expressed as $50 \%$ soybean $+50 \%$ sunflower

In addition to sole crops:

1. Sole sunflower: pure stand of sunflower ridge $(60 \mathrm{~cm}$ width) by growing one plant/hill spaced at $20 \mathrm{~cm}$ that received $142.8 \mathrm{~kg} \mathrm{~N} / \mathrm{ha}$ as urea. This pattern was used only for land equivalent ratio.

2. Sole soybean: pure stand of soybean ridge $(60 \mathrm{~cm}$ width $)$ by growing two rows in both sides of the ridge (two plants/hill distanced at $20 \mathrm{~cm}$ ). This pattern was used only for land equivalent ratio.

A split-plot design with three replicates was used. Treatments of sunflower plant spacing randomly assigned to the main plots and mineral $\mathrm{N}$ fertilizer rates of sunflower were allocated in sub-plots. The area of sub plot was $10.8 \mathrm{~m}^{2}$, it consisted of six ridges, and each ridge was $3.0 \mathrm{~m}$ in length and $0.6 \mathrm{~m}$ in width

\subsection{The Studied Traits}

\subsubsection{Yield and Its Attributes of Soybean}

At harvest, the following traits were measured on ten plants from each sub plot: Plant height $(\mathrm{cm})$, seed yield per plant $(\mathrm{g})$ and 100 - seed weight $(\mathrm{g})$. Biological and seed yields per ha (ton) were recorded on the basis of experimental sub plot area by harvesting all plants of each plot. Protein yield per ha (ton) was calculated by multiplying crude protein content (\%) x seed yield per ha (ton). Also, oil yield per ha (ton) was calculated by crude oil content (\%) $\mathrm{x}$ seed yield (ton per ha). Also, harvest index was estimated according to Clipson et al. [18]: economic yield/biological yield x 100 .

\subsubsection{Yield and Its Attributes of Sunflower}

At harvest, the following traits were measured on ten plants from each sub plot: Plant height $(\mathrm{cm})$, number of leaves per plant, stem and head diameters, 1000 - seed weight (g) and head seed weight. Seed yield per ha (ton) was recorded on the basis of experimental sub plot area by harvesting all plants of each plot. Oil yield per ha (ton) was calculated by crude oil content (\%) x seed yield per ha (ton). 


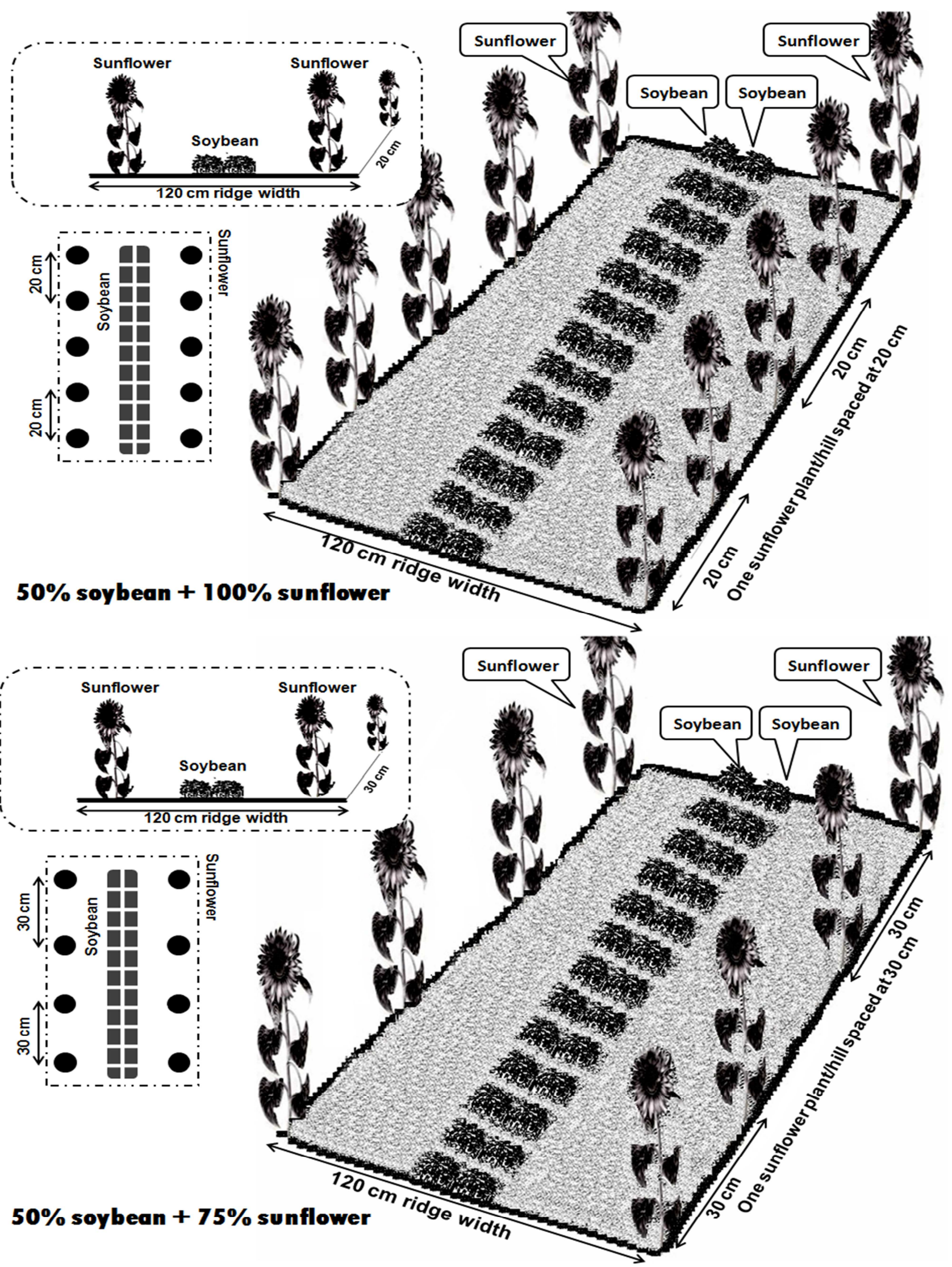




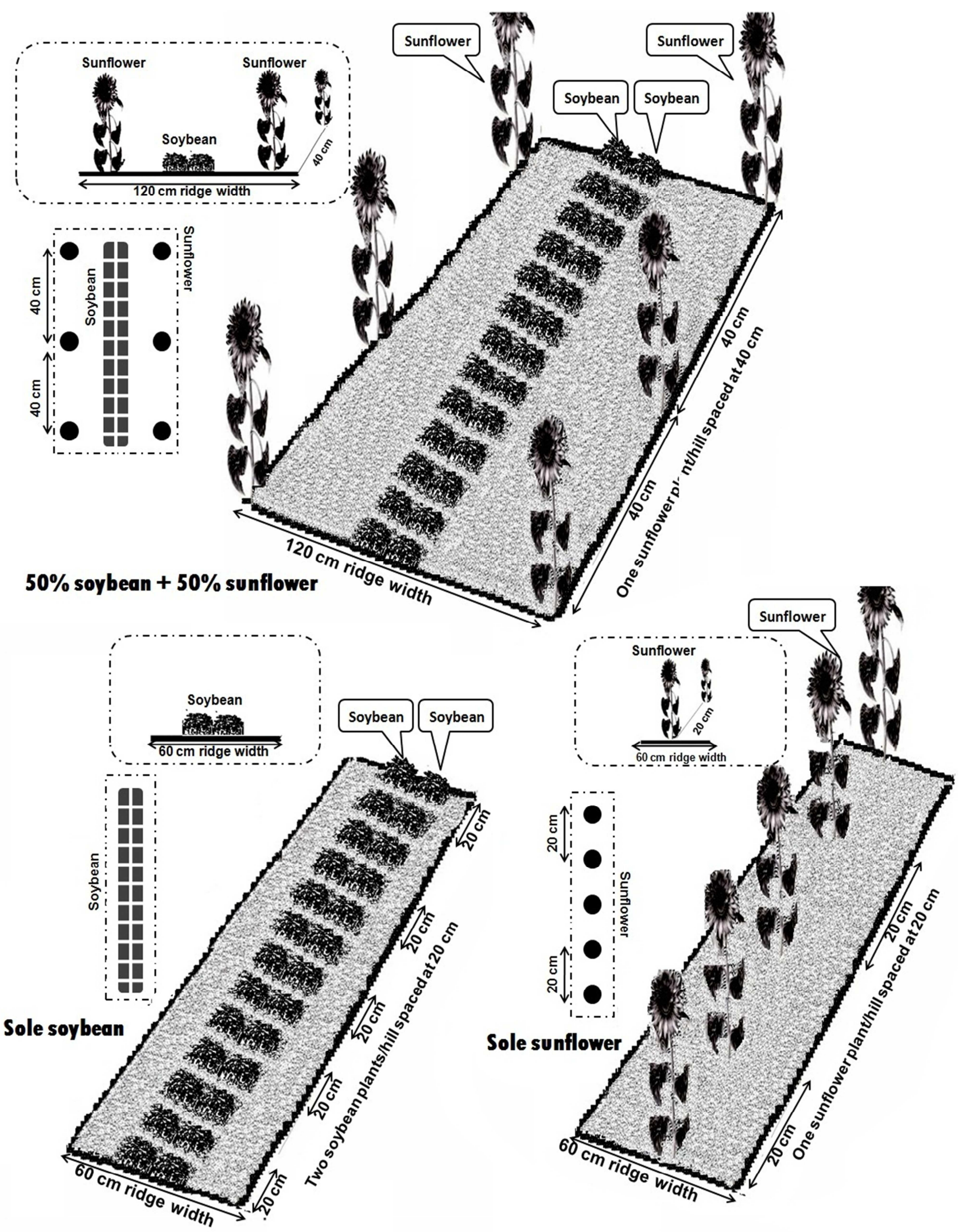

Figure 1. Intercropping soybean with sunflower under different plant spacings and sole cultures of both crops.

\subsubsection{Quality of Soybean and Sunflower Seeds}

Samples of 50 grams from each of soybean and sunflower seeds were air dried, then ground and the fine powder stored in brown glass bottles. All the chemical determinations were estimated in ground seeds dried at $70^{\circ} \mathrm{C}$ till constant weight. The total $\mathrm{N}$ of soybean seeds was determined using Microkjeldahl apparatus according to A.O.A.C. [19]. Crude protein 
content of soybean seeds was calculated by multiplying total $\mathrm{N}$ by 5.71 [20]. Crude oil contents of soybean and sunflower seeds were determined using Soxhlet apparatus and Nhexane as a solvent [19]. Fatty acids were separated according to Vogel [21] and identified by Gas Liquids Chromatography, Trace GC Ultra, Thermo Scientific (GLC) apparatus according to Farag et al. [22]. These analyses were done by Seed Technology Research Department, Field Crops Research Institute, ARC.

\subsubsection{Land Equivalent Ratio (LER)}

LER defines as the ratio of area needed under sole cropping to one of intercropping at the same management level to produce an equivalent yield [23]. It is calculated as follows: $\mathrm{LER}=\left(\mathrm{Y}_{\mathrm{ab}} / \mathrm{Y}_{\mathrm{aa}}\right)+\left(\mathrm{Y}_{\mathrm{ba}} / \mathrm{Y}_{\mathrm{bb}}\right)$, Where $\mathrm{Y}_{\mathrm{aa}}=$ Pure stand yield of crop a (sunflower), $\mathrm{Y}_{\mathrm{bb}}=$ Pure stand yield of crop b (soybean), $\mathrm{Y}_{\mathrm{ab}}=$ Intercrop yield of crop a (sunflower) and $\mathrm{Y}_{\mathrm{ba}}=$ Intercrop yield of crop $\mathrm{b}$ (soybean).

\subsubsection{Farmer's Benefit}

Farmer's benefit (US\$) was calculated as a difference between total net returns from intercropping and sole crops. Sunflower and soybean seeds prices presented by Bulletin of Statistical Cost Production and Net Return [24] were used. Net returns were calculated by subtraction the sum of fixed cost of sunflower plus variable costs of both crops according to sunflower plant spacing and Mineral $\mathrm{N}$ fertilizer rates.

\subsection{Statistical Manipulation}

Analysis of variance of the obtained results of each season was performed. The homogeneity test was conducted of error mean squares and accordingly, the combined analysis of the two experimental seasons was carried out. The measured variables were analyzed by ANOVA using MSTATC statistical package [25]. Mean comparisons were performed using the least significant differences (L.S.D) test with a significance level of 5\% [26].

\section{Results and Discussion}

\subsection{Soybean Seed Yield and Its Attributes}

\subsubsection{Effect of Sunflower Plant Spacing}

Biological yield per ha, plant height, seed yield per plant, 100 - seed weight, seed yield per ha, harvest index, protein and oil yields per ha were affected significantly by sunflower plant spacing in the combined data across 2014 and 2015 seasons (Table 2). Biological yield per ha, seed yield per plant, 100 - seed weight, seed yield per ha, harvest index and protein and oil yields per ha were increased significantly by increasing sunflower plant density from 50 to $100 \%$ of sole sunflower. Conversely, plant height of soybean was decreased significantly by increasing spacing between sunflower plants from 20 to $40 \mathrm{~cm}$. These data may be due to intercropping soybean with sunflower plants that spaced at $20 \mathrm{~cm}$ between hills (50\% soybean $+100 \%$ sunflower $)$ affected negatively the responses of soybean plant to intercept more solar radiation compared to those grown with the other sunflower plant spacings under sandy soil conditions. It is important to mention that sunflower plant density per unit area could be related to the proportion of solar radiation that reaches soybean plants under intercropping culture during growth and development of soybean. Intercropping soybean with the narrowest sunflower plant spacing $(50 \%$ soybean $+100 \%$ sunflower $)$ led to acclimation of the legume component to low light intensity under intercropping conditions. Accordingly, it is expected that there was more shading around soybean plants that suffered from mutual shading compared to those grown with the other sunflower plant spacings. Mutual shading is known to increase the proportion of invisible radiation, which has a specific elongating effect upon plants [27]. Obviously, plant height of intercropped soybean with the narrowest plant spacing of sunflower was increased $(P \leq 0.05)$ by $9.02 \%$ than those grown with the widest plant spacing of sunflower.

However, plant height of soybean was not affected $(P>$ 0.05 ) by decreasing plant density of sunflower from 100 to $75 \%$ of sole sunflower. Consequently, these results reveal that shading effects of the highest sunflower plant density per unit area could be formed unfavorable environmental conditions for soybean growth and development which increased plant hormones of soybean. So, the observed response in plant height of intercropped soybean with high plant density of sunflower (50\% soybean $+100 \%$ sunflower) could be primarily attributed to an increase of internodes number and elongation of soybean plant as a result of increasing plant hormones under sandy soil conditions. These results are in parallel with those obtained by Gadallah et al. [28] who found that intercropping soybean with sunflower that grown as one plant spaced at $25 \mathrm{~cm}$ had the highest values of plant height compared to the other sunflower plant distributions

Table 2. Effect of sunflower plant spacing, slow - release N fertilizer and their interaction on soybean seed yield and its attributes, combined data across 2014 and 2015 seasons.

\begin{tabular}{|c|c|c|c|c|c|c|c|c|c|c|c|c|}
\hline \multirow{2}{*}{ Treatments } & \multicolumn{4}{|c|}{ Biological yield/ha (ton) } & \multicolumn{4}{|c|}{ Plant height (cm) } & \multicolumn{4}{|c|}{ Seed yield/plant (g) } \\
\hline & $\mathbf{U F}_{\mathbf{0}}$ & $\mathbf{U F}_{1}$ & $\mathbf{U F}_{2}$ & Mean & $\mathbf{U F}_{\mathbf{0}}$ & $\mathbf{U F}_{1}$ & $\mathbf{U F}_{2}$ & Mean & $\mathbf{U F}_{\mathbf{0}}$ & $\mathbf{U F}_{1}$ & $\mathbf{U F}_{2}$ & Mean \\
\hline $50 \%$ soybean $+100 \%$ sunflower & 4.01 & 4.35 & 4.38 & 4.24 & 103.21 & 100.66 & 102.38 & 102.08 & 7.43 & 7.51 & 7.48 & 7.47 \\
\hline $50 \%$ soybean $+75 \%$ sunflower & 5.46 & 5.55 & 5.38 & 5.46 & 97.88 & 96.41 & 96.18 & 96.82 & 8.99 & 9.08 & 8.92 & 8.99 \\
\hline $50 \%$ soybean $+50 \%$ sunflower & 6.49 & 6.80 & 6.72 & 6.67 & 94.52 & 93.05 & 93.32 & 93.63 & 9.51 & 9.48 & 9.59 & 9.52 \\
\hline Mean & 5.32 & 5.56 & 5.49 & 5.45 & 98.53 & 96.70 & 97.29 & 97.50 & 8.64 & 8.69 & 8.66 & 8.66 \\
\hline \multicolumn{4}{|l|}{ L.S.D. 0.05 Sunflower plant spacing } & 2.24 & & & & 7.62 & & & & 0.98 \\
\hline \multicolumn{4}{|c|}{ L.S.D. 0.05 Slow - release N fertilizer } & N.S. & & & & N.S. & & & & N.S. \\
\hline
\end{tabular}




\begin{tabular}{|c|c|c|c|c|c|c|c|c|c|c|c|c|}
\hline \multirow{2}{*}{ Treatments } & \multicolumn{4}{|c|}{ Biological yield/ha (ton) } & \multicolumn{4}{|c|}{ Plant height (cm) } & \multicolumn{4}{|c|}{ Seed yield/plant (g) } \\
\hline & $\mathbf{U F}_{\mathbf{0}}$ & $\mathbf{U F}_{1}$ & $\mathbf{U F}_{2}$ & Mean & $\mathbf{U F}_{\mathbf{0}}$ & $\mathbf{U F}_{1}$ & $\mathbf{U F}_{2}$ & Mean & $\mathbf{U F}_{\mathbf{0}}$ & $\mathbf{U F}_{1}$ & $\mathbf{U F}_{2}$ & Mean \\
\hline Sole soybean & & & & 14.23 & & & & 91.77 & & & & 10.18 \\
\hline & \multicolumn{4}{|c|}{100 - seed weight (g) } & \multicolumn{4}{|c|}{ Seed yield/ha (ton) } & \multicolumn{4}{|c|}{ Harvest index (\%) } \\
\hline Treatments & $\mathrm{UF}_{0}$ & $\mathrm{UF}_{1}$ & $\mathrm{UF}_{2}$ & Mean & $\mathrm{UF}_{0}$ & $\mathrm{UF}_{1}$ & $\mathrm{UF}_{2}$ & Mean & $\mathrm{UF}_{0}$ & $\mathrm{UF}_{1}$ & $\mathrm{UF}_{2}$ & Mean \\
\hline $50 \%$ soybean $+100 \%$ sunflower & 14.32 & 14.44 & 14.27 & 14.34 & 0.82 & 0.89 & 0.89 & 0.86 & 20.44 & 20.45 & 20.31 & 20.40 \\
\hline $50 \%$ soybean $+75 \%$ sunflower & 14.73 & 14.79 & 14.69 & 14.73 & 1.15 & 1.18 & 1.13 & 1.15 & 21.06 & 21.26 & 21.00 & 21.10 \\
\hline $50 \%$ soybean $+50 \%$ sunflower & 15.21 & 15.10 & 15.08 & 15.13 & 1.40 & 1.46 & 1.44 & 1.43 & 21.57 & 21.47 & 21.42 & 21.48 \\
\hline Mean & 14.75 & 14.77 & 14.68 & 14.73 & 1.12 & 1.17 & 1.15 & 1.14 & 21.02 & 21.06 & 20.91 & 20.99 \\
\hline \multicolumn{4}{|c|}{ L.S.D. 0.05 Sunflower plant spacing } & 0.71 & & & & 0.49 & & & & 0.89 \\
\hline \multicolumn{4}{|c|}{ L.S.D. 0.05 Slow - release $\mathrm{N}$ fertilizer } & N.S. & & & & N.S. & & & & N.S. \\
\hline \multicolumn{4}{|l|}{ L.S.D. 0.05 Interaction } & N.S. & & & & N.S. & & & & N.S. \\
\hline Sole soybean & & & & 17.63 & & & & 3.18 & & & & 22.34 \\
\hline & \multicolumn{4}{|c|}{ Protein yield/ha (ton) } & \multicolumn{4}{|c|}{ Oil yield/ha (ton) } & & & & \\
\hline Ireatments & $\mathrm{UF}_{0}$ & $\mathrm{UF}_{1}$ & $\mathrm{UF}_{2}$ & Mean & $\mathrm{UF}_{0}$ & $\mathrm{UF}_{1}$ & $\mathrm{UF}_{2}$ & Mean & & & & \\
\hline $50 \%$ soybean $+100 \%$ sunflower & 0.32 & 0.35 & 0.35 & 0.34 & 0.17 & 0.18 & 0.18 & 0.17 & & & & \\
\hline $50 \%$ soybean $+75 \%$ sunflower & 0.44 & 0.46 & 0.44 & 0.44 & 0.24 & 0.25 & 0.24 & 0.24 & & & & \\
\hline $50 \%$ soybean $+50 \%$ sunflower & 0.53 & 0.56 & 0.55 & 0.54 & 0.30 & 0.32 & 0.31 & 0.31 & & & & \\
\hline Mean & 0.43 & 0.45 & 0.44 & 0.44 & 0.23 & 0.25 & 0.24 & 0.24 & & & & \\
\hline \multicolumn{4}{|c|}{ L.S.D. 0.05 Sunflower plant spacing } & 0.18 & & & & 0.11 & & & & \\
\hline \multicolumn{4}{|c|}{ L.S.D. 0.05 Slow - release $\mathrm{N}$ fertilizer } & N.S. & & & & N.S. & & & & \\
\hline \multicolumn{4}{|c|}{ L.S.D. 0.05 Interaction } & N.S. & & & & N.S. & & & & \\
\hline \multicolumn{4}{|l|}{ Sole soybean } & 1.21 & & & & 0.72 & & & & \\
\hline
\end{tabular}

On the other hand, decreasing sunflower plant density from 100 to $50 \%$ of sole sunflower increased $(P \leq 0.05)$ seed yield per plant, 100 - seed weight, seed yield per ha, harvest index, protein and oil yields per ha. These data may be attributed to increase in plant spacing of sunflower from 20 to $40 \mathrm{~cm}$ increased intercepted light intensity by soybean canopy which reflected positively on seed yield per plant, 100 - seed weight and harvest index. These results are in accordance with those obtained by Metwally et al. [29] who concluded that intercropping sunflower with soybean (4:2) mainly attributed to more light use efficiency of solar radiation utilized by soybean plants, which minimize the competition between soybean plants, as well as, soybean and sunflower plants for light and consequently encourages the dry matter accumulation.

\subsubsection{Effect of Slow-Release N Fertilizer}

Biological yield per ha, plant height, seed yield per plant, 100 - seed weight, seed yield per ha, harvest index, protein and oil yields per ha were not affected significantly by slow release $\mathrm{N}$ fertilizer rates of sunflower in the combined data across 2014 and 2015 seasons (Table 2). From self-evident, there was no relationship between slow-release $\mathrm{N}$ fertilizer rates of sunflower and the studied traits of soybean.

\subsubsection{Response of Sunflower Plant Spacing to Slow- Release N Fertilizer}

Biological yield per ha, plant height, seed yield per plant, 100 - seed weight, seed yield per ha, harvest index and protein and oil yields per ha were not affected significantly by sunflower plant spacing $\mathrm{x}$ slow - release $\mathrm{N}$ fertilizer rates of sunflower in the combined data across 2014 and 2015 seasons (Table 2). Concerning competition for $\mathrm{N}$ fertilizer in sunflower-soybean intercropping, the bean component is capable of fixing atmospheric $\mathrm{N}_{2}$ under favorable condition.
From self-evident, there was no relationship between the interaction of sunflower plant spacing with slow-release $\mathrm{N}$ fertilizer rates of sunflower and the studied traits of soybean. So, the biological $\mathrm{N}$ fixation by the bean component should be considered, but in this experiment, there was no way to determine the amount of $\mathrm{N}$ derived from fixation and absorption from the soil. These data show that each of these factors act independently on all the studied traits of soybean meaning that sunflower plant spacing responded similarly $(P>$ $0.05)$ to slow-release $\mathrm{N}$ fertilizer rates of sunflower for biological yield per ha, plant height, seed yield per plant, 100 - seed weight, seed yield per ha, harvest index, protein and oil yields per ha.

\subsection{Quality of Soybean Seeds}

\subsubsection{Effect of Sunflower Plant Spacing}

Quality of soybean seeds (N, protein and oil contents) was affected significantly by sunflower plant spacing in the combined data across 2014 and 2015 seasons (Table 3). Decreasing sunflower plant density from 100 to $50 \%$ of sole sunflower by increasing plant spacing of sunflower from 20 to $40 \mathrm{~cm}$ increased $(P \leq 0.05)$ seed oil content but it decreased seed $\mathrm{N}$ and protein contents. Consequently, intercropping soybean with sunflower plants that spaced at $20 \mathrm{~cm}$ between hills $(50 \%$ soybean $+100 \%$ sunflower $)$ had the lowest seed oil content but it achieved the highest seed $\mathrm{N}$ and protein contents compared to the others. These results are in accordance with those obtained by Metwally et al. [30] who indicated that there is significant reduction in seed oil content of soybean by decreasing distance between maize hills from 60 to $30 \mathrm{~cm}$. Also, Abdel-Galil et al. [31] showed that decreasing maize plant spacing from 90 to $30 \mathrm{~cm}$ decreased seed oil content but it increased seed protein content of soybean. 
39 Sherif Ibrahim Abdel-Wahab and Amal Mahmoud El Manzlawy: Yield and Quality of Intercropped Sunflower with Soybean Under Different Sunflower Plant Spacings and Slow - Release Nitrogen Fertilizer Rates in Sandy Soil

Table 3.Effect of sunflower plant spacing, slow - release $N$ fertilizer and their interaction on quality of soybean seeds, combined data across 2014 and 2015 seasons.

\begin{tabular}{|c|c|c|c|c|c|c|c|c|c|c|c|c|}
\hline \multirow{2}{*}{ Treatments } & \multicolumn{4}{|c|}{ Seed oil content $(\%)$} & \multicolumn{4}{|c|}{ Seed $N$ content $(\%)$} & \multicolumn{4}{|c|}{ Seed protein content } \\
\hline & $\mathbf{U F}_{\mathbf{0}}$ & $\mathbf{U F}_{1}$ & $\mathbf{U F}_{2}$ & Mean & $\mathbf{U F}_{0}$ & $\mathbf{U F}_{1}$ & $\mathbf{U F}_{2}$ & Mean & $\mathbf{U F}_{\mathbf{0}}$ & $\mathbf{U F}_{1}$ & $\mathbf{U F}_{2}$ & Mean \\
\hline $50 \%$ soybean $+100 \%$ sunflower & 21.09 & 21.21 & 21.12 & 21.14 & 6.91 & 6.93 & 6.95 & 6.93 & 39.49 & 39.60 & 39.74 & 39.61 \\
\hline $50 \%$ soybean $+75 \%$ sunflower & 21.52 & 21.58 & 21.44 & 21.51 & 6.82 & 6.85 & 6.88 & 6.85 & 38.96 & 39.13 & 39.32 & 39.13 \\
\hline $50 \%$ soybean $+50 \%$ sunflower & 21.97 & 22.11 & 21.86 & 21.98 & 6.71 & 6.74 & 6.78 & 6.74 & 38.32 & 38.51 & 38.76 & 38.53 \\
\hline Mean & 21.52 & 21.63 & 21.47 & 21.54 & 6.81 & 6.84 & 6.87 & 6.84 & 38.92 & 39.08 & 39.27 & 39.09 \\
\hline \multicolumn{4}{|l|}{ L.S.D. 0.05 Sunflower plant spacing } & 0.72 & & & & 0.17 & & & & 0.94 \\
\hline \multicolumn{4}{|c|}{ L.S.D. 0.05 Slow - release $N$ fertilizer } & N.S. & & & & N.S. & & & & N.S. \\
\hline \multicolumn{4}{|l|}{ Sole soybean } & 22.78 & & & & 6.69 & & & & 38.22 \\
\hline
\end{tabular}

\subsubsection{Effect of Slow - Release $N$ Fertilizer}

Quality of soybean seeds (N, protein and oil contents) was not affected significantly by slow - release $\mathrm{N}$ fertilizer rates of sunflower in the combined data across 2014 and 2015 seasons (Table 3). From self-evident, there was no relationship between slow-release $\mathrm{N}$ fertilizer rates of sunflower and quality of soybean seeds.

\subsubsection{Response of Sunflower Plant Spacing to Slow- Release $N$ Fertilizer}

Quality of soybean seeds (N, protein and oil contents) was not affected significantly by sunflower plant spacing $\mathrm{x}$ slow release $\mathrm{N}$ fertilizer rates of sunflower in the combined data across 2014 and 2015 seasons (Table 3). From self-evident, there was no relationship between the interaction of sunflower plant spacing with slow-release $\mathrm{N}$ fertilizer rates of sunflower and quality of soybean seeds.

\subsection{Sunflower Seed Yield and Its Attributes}

\subsubsection{Effect of Sunflower Plant Spacing}

Plant height, stem and head diameters, 1000 - seed weight, head seed weight and seed and oil yields per ha were affected significantly by sunflower plant spacing in the combined data across 2014 and 2015 seasons, meanwhile, number of leaves per plant was not affected (Table 4). Decreasing plant spacing of sunflower from 40 to $20 \mathrm{~cm}$ increased $(P \leq 0.05)$ plant height, seed and oil yields per ha. Clearly, sunflower plant density per unit area is one of the major factors that determining ability of the plant to capture light energy where plant height, seed and oil yields per ha were increased $(P \leq$ 0.05 ) by $24.33,66.29$ and $68.33 \%$, respectively, as a result of increasing sunflower plant density per unit area from 50 to $100 \%$ of sole sunflower under sandy soil conditions. These results are in accordance to those obtained by Gadallah et al.
[28] who indicated that seed yield of intercropped sunflower with soybean was increased with increasing sunflower plant density to $100 \%$ of sole sunflower.

Conversely, stem and head diameters, 1000 - seed weight and head seed weight were increased significantly by increasing sunflower plant spacing from 20 to $40 \mathrm{~cm}$. It seemed that intercropping soybean with sunflower plants that spaced at $20 \mathrm{~cm}$ between hills $(50 \%$ soybean $+100 \%$ sunflower) increased intra-specific competition between sunflower plants for basic growth resources especially solar radiation which reflected on little dry matter accumulation during sunflower growth and development compared to the others. Similar results were obtained by Sûzer [32] who investigated that increasing sunflower plant densities per unit area decreased 1000-seed weight and head diameter.

\subsubsection{Effect of Slow - Release N Fertilizer}

Plant height, stem and head diameters, 1000 - seed weight, head seed weight, seed and oil yields per ha were affected significantly by slow - release $\mathrm{N}$ fertilizer rates of sunflower in the combined data across 2014 and 2015 seasons, meanwhile, number of leaves per plant was not affected (Table 4). Sunflower plants with the application of $\mathrm{UF}_{0}$ or $\mathrm{UF}_{1}$ had higher values of plant height, stem and head diameter, 1000 - seed weight, head seed weight and seed and oil yields per ha than those with the application of $U_{2}$. These data may be attributed to the favorable effect of the highest mineral $\mathrm{N}$ fertilizer rate $(142.8 \mathrm{~kg} \mathrm{~N} / \mathrm{ha})$ on the metabolic processes and physiological activates of meristimatic tissues, which are responsible for cell division and elongation in addition to formation of the plant organs. This leads to more vigorous growth and consequently accumulation of more photosynthesis assimilates which resulted in greater head seed weight.

Table 4. Effect of sunflower plant spacing, slow - release $N$ fertilizer and their interaction on sunflower seed yield and its attributes, combined data across 2014 and 2015 seasons.

\begin{tabular}{|c|c|c|c|c|c|c|c|c|c|c|c|c|}
\hline \multirow{2}{*}{ Treatments } & \multicolumn{4}{|c|}{ Plant height (cm) } & \multicolumn{4}{|c|}{ Number of leaves/plant } & \multicolumn{4}{|c|}{ Stem diameter $(\mathrm{cm})$} \\
\hline & $\mathbf{U F}_{\mathbf{0}}$ & $\mathbf{U F}_{1}$ & $\mathbf{U F}_{2}$ & Mean & $\mathbf{U F}_{\mathbf{0}}$ & $\mathbf{U F}_{1}$ & $\mathbf{U F}_{2}$ & Mean & $\mathbf{U F}_{\mathbf{0}}$ & $\mathbf{U F}_{1}$ & $\mathbf{U F}_{2}$ & Mean \\
\hline $50 \%$ soybean $+100 \%$ sunflower & 148.78 & 147.92 & 143.12 & 196.60 & 21.22 & 21.50 & 21.03 & 21.25 & 3.47 & 3.32 & 3.08 & 3.29 \\
\hline $50 \%$ soybean $+75 \%$ sunflower & 139.02 & 138.33 & 134.89 & 177.41 & 21.32 & 21.11 & 20.88 & 21.10 & 3.58 & 3.46 & 3.19 & 3.41 \\
\hline $50 \%$ soybean $+50 \%$ sunflower & 130.45 & 129.67 & 124.26 & 158.12 & 20.97 & 20.83 & 21.25 & 21.01 & 3.77 & 3.65 & 3.33 & 3.58 \\
\hline Mean & 179.41 & 178.64 & 174.09 & 177.38 & 21.17 & 21.14 & 21.05 & 21.12 & 3.60 & 3.47 & 3.20 & 3.42 \\
\hline \multirow{2}{*}{\multicolumn{3}{|c|}{$\begin{array}{l}\text { L.S.D. } 0.05 \text { Sunflower plant spacing } \\
\text { L.S.D. } 0.05 \text { Slow - release } \mathrm{N} \text { fertilizer } \\
\text { L.S.D. } 0.05 \text { Interaction }\end{array}$}} & & 5.33 & & & & N.S. & & & & 0.22 \\
\hline & & & & 4.18 & & & & N.S. & & & & 0.17 \\
\hline
\end{tabular}




\begin{tabular}{|c|c|c|c|c|c|c|c|c|c|c|c|c|}
\hline \multirow{2}{*}{ Treatments } & \multicolumn{4}{|c|}{ Plant height (cm) } & \multicolumn{4}{|c|}{ Number of leaves/plant } & \multicolumn{4}{|c|}{ Stem diameter $(\mathrm{cm})$} \\
\hline & $\mathbf{U F}_{\mathbf{0}}$ & $\mathbf{U F}_{1}$ & $\mathbf{U F}_{2}$ & Mean & $\mathbf{U F}_{\mathbf{0}}$ & $\mathbf{U F}_{1}$ & $\mathbf{U F}_{2}$ & Mean & $\mathbf{U F}_{\mathbf{0}}$ & $\mathbf{U F}_{1}$ & $\mathbf{U F}_{2}$ & Mean \\
\hline Sole sunflower & & & & 148.65 & & & & 21.55 & & & & 3.39 \\
\hline & \multicolumn{4}{|c|}{ Head diameter (cm) } & \multicolumn{4}{|c|}{1000 - seed weight $(\mathrm{g})$} & \multicolumn{4}{|c|}{ Head seed weight (g) } \\
\hline Treatments & $\mathrm{UF}_{0}$ & $\mathrm{UF}_{1}$ & $\mathrm{UF}_{2}$ & Mean & $\mathrm{UF}_{0}$ & $\mathrm{UF}_{1}$ & $\mathrm{UF}_{2}$ & Mean & $\mathrm{UF}_{0}$ & $\mathrm{UF}_{1}$ & $\mathrm{UF}_{2}$ & Mean \\
\hline $50 \%$ soybean $+100 \%$ sunflower & 22.94 & 22.71 & 21.10 & 22.25 & 55.13 & 55.92 & 52.34 & 54.46 & 60.22 & 60.08 & 59.42 & 59.90 \\
\hline $50 \%$ soybean $+75 \%$ sunflower & 23.67 & 23.49 & 21.96 & 23.04 & 56.80 & 56.59 & 52.87 & 55.42 & 62.89 & 62.70 & 61.16 & 62.25 \\
\hline $50 \%$ soybean $+50 \%$ sunflower & 24.25 & 24.02 & 22.38 & 23.55 & 58.33 & 58.02 & 53.26 & 56.53 & 64.41 & 64.21 & 61.53 & 63.38 \\
\hline Mean & 23.62 & 23.40 & 21.81 & 22.94 & 56.75 & 56.84 & 52.82 & 55.47 & 62.50 & 62.33 & 60.70 & 61.84 \\
\hline \multicolumn{4}{|c|}{ L.S.D. 0.05 Sunflower plant spacing } & 0.66 & & & & 0.57 & & & & 1.44 \\
\hline \multicolumn{4}{|c|}{ L.S.D. 0.05 Slow - release $\mathrm{N}$ fertilizer } & 0.47 & & & & 0.43 & & & & 0.85 \\
\hline \multicolumn{4}{|c|}{ L.S.D. 0.05 Interaction } & 0.82 & & & & 0.64 & & & & 1.91 \\
\hline Sole sunflower & & & & 22.81 & & & & 55.22 & & & & 60.31 \\
\hline & \multicolumn{4}{|c|}{ Seed yield/ha (ton) } & \multicolumn{4}{|c|}{ Oil yield/ha (ton) } & & & & \\
\hline Ireatments & $\mathrm{UF}_{0}$ & $\mathrm{UF}_{1}$ & $\mathrm{UF}_{2}$ & Mean & $\mathrm{UF}_{0}$ & $\mathrm{UF}_{1}$ & $\mathrm{UF}_{2}$ & Mean & & & & \\
\hline $50 \%$ soybean $+100 \%$ sunflower & 3.22 & 3.11 & 2.72 & 3.01 & 1.12 & 1.11 & 0.82 & 1.01 & & & & \\
\hline $50 \%$ soybean $+75 \%$ sunflower & 2.73 & 2.68 & 2.15 & 2.52 & 0.95 & 0.94 & 0.62 & 0.83 & & & & \\
\hline $50 \%$ soybean $+50 \%$ sunflower & 2.02 & 1.89 & 1.54 & 1.81 & 0.71 & 0.67 & 0.44 & 0.60 & & & & \\
\hline Mean & 2.65 & 2.56 & 2.13 & 2.44 & 0.92 & 0.90 & 0.62 & 0.81 & & & & \\
\hline \multicolumn{4}{|c|}{ L.S.D. 0.05 Sunflower plant spacing } & 0.33 & & & & 0.17 & & & & \\
\hline \multicolumn{4}{|c|}{ L.S.D. 0.05 Slow - release $\mathrm{N}$ fertilizer } & 0.24 & & & & 0.11 & & & & \\
\hline \multicolumn{4}{|c|}{ L.S.D. 0.05 Interaction } & 0.39 & & & & 0.23 & & & & \\
\hline \multicolumn{4}{|l|}{ Sole sunflower } & 3.21 & & & & 1.15 & & & & \\
\hline
\end{tabular}

However, there were no significant differences between the application of $\mathrm{UF}_{0}$ and $\mathrm{UF}_{1}$. Beneficial effect of the application of $\mathrm{UF}_{1}$ could be attributed to coating material on sunflower plants regulated $\mathrm{N}$ release and reduced $\mathrm{N}$-leaching losses that provided a constant supply of $\mathrm{N}$ to roots of sunflower plants under sandy soil conditions. In other words, sandy soil is very low water holding capacity and high nutrient leaching losses, sunflower plants with the application of $\mathrm{UF}_{1}$ maintained the $\mathrm{N}$ losses as volatilization or leaching. In this concern, Ahmed [33] found that fertilization with readily soluble or slow-release $\mathrm{N}$ - fertilizers in sunflower plant enhanced plant height, stem diameter and head diameter compared with the untreated one.

\subsubsection{Response of Sunflower Plant Spacing to Slow- Release $N$ Fertilizer}

Plant height, stem and head diameters, 1000 - seed weight, head seed weight and seed and oil yields per ha were affected significantly by sunflower plant spacing $\mathrm{x}$ slow - release $\mathrm{N}$ fertilizer rates of sunflower in the combined data across 2014 and 2015 seasons, meanwhile, number of leaves per plant was not affected (Table 4). Intercropping soybean with sunflower plants that spaced at $20 \mathrm{~cm}$ between hills $(50 \%$ soybean $+100 \%$ sunflower) interacted positively with the application of $\mathrm{UF}_{0}$ or $\mathrm{UF}_{1}$ to give the highest values of plant height, seed and oil yields per ha compared to the other treatments under sandy soil conditions. On the other hand, the negative effect of the narrowest sunflower plant spacing (20 $\mathrm{cm}$ between hills) that received $\mathrm{UF}_{2}$ on the yield attributes could be due to high intra-specific competition between sunflower plants for basic growth resources especially solar radiation and soil N. N comprises $7 \%$ of total dry matter of plants and is a constituent of many fundamental cell components such as nucleic acids and photosynthetic pigments [34]. These data reveal that there was effect
$(P \leq 0.05)$ of sunflower plant spacing $\mathrm{x}$ slow-release $\mathrm{N}$ fertilizer rates of sunflower on plant height, stem and head diameters, 1000 - seed weight, head seed weight and seed and oil yields per ha.

\subsection{Quality of Sunflower Seeds}

\subsubsection{Effect of Sunflower Plant Spacing}

Quality of sunflower seeds (seed oil content, total unsaturated and saturated fatty acids) was not affected significantly by sunflower plant spacing in the combined data across 2014 and 2015 seasons (Table 5). It is important to mention that quality of sunflower seeds (seed oil content, total unsaturated and saturated fatty acids) was not affected $(P>0.05)$ by decreasing sunflower plant density from 100 to $50 \%$ of sole sunflower. These results are in accordance with those obtained by Al-Thabet [35] who investigated that plant spacing of sunflower did not affect seed oil percentage.

\subsubsection{Effect of Slow - Release N Fertilizer}

Quality of sunflower seeds (seed oil content, total unsaturated and saturated fatty acids) was affected significantly by slow - release $\mathrm{N}$ fertilizer rates of sunflower in the combined data across 2014 and 2015 seasons (Table 5). Sunflower plants with the application of $\mathrm{UF}_{0}$ or $\mathrm{UF}_{1}$ increased $(P \leq 0.05)$ unsaturated fatty acids but it decreased seed oil content and saturated fatty acids as compared to those with the application of $\mathrm{UF}_{2}$. Increasing mineral $\mathrm{N}$ fertilizer rate achieved the maximum sunflower seed production with good quality [36]. It seems that there is an negative correlation between seed oil content and unsaturated fatty acids in this study where increasing $\mathrm{N}$ levels resulted in steady increases in yield and linoleic acid (unsaturated fatty acid), but it decreased oil content and palmitic acid (saturated fatty acid) during both years [15]. 
41 Sherif Ibrahim Abdel-Wahab and Amal Mahmoud El Manzlawy: Yield and Quality of Intercropped Sunflower with Soybean Under Different Sunflower Plant Spacings and Slow - Release Nitrogen Fertilizer Rates in Sandy Soil

Table 5.Effect of sunflower plant spacing, slow - release $N$ fertilizer and their interaction on quality of sunflower seeds, combined data across 2014 and 2015 seasons.

\begin{tabular}{|c|c|c|c|c|c|c|c|c|c|c|c|c|}
\hline \multirow{2}{*}{ Treatments } & \multicolumn{4}{|c|}{ Seed oil content $(\%)$} & \multicolumn{4}{|c|}{ Total unsaturated fatty acids (\%) } & \multicolumn{4}{|c|}{ Total saturated fatty acids (\%) } \\
\hline & $\mathbf{U F}_{\mathbf{0}}$ & $\mathbf{U F}_{1}$ & $\mathbf{U F}_{2}$ & Mean & $\mathbf{U F}_{\mathbf{0}}$ & $\mathbf{U F}_{1}$ & $\mathbf{U F}_{2}$ & Mean & $\mathbf{U F}_{\mathbf{0}}$ & $\mathbf{U F}_{1}$ & $\mathbf{U F}_{2}$ & Mean \\
\hline $50 \%$ soybean $+100 \%$ sunflower & 34.93 & 35.27 & 35.61 & 35.27 & 86.56 & 86.31 & 86.09 & 86.32 & 6.21 & 6.43 & 6.67 & 6.43 \\
\hline $50 \%$ soybean $+75 \%$ sunflower & 35.15 & 35.43 & 35.82 & 35.46 & 86.37 & 86.12 & 85.92 & 86.13 & 6.39 & 6.68 & 6.93 & 6.66 \\
\hline $50 \%$ soybean $+50 \%$ sunflower & 35.48 & 35.74 & 36.09 & 35.77 & 86.17 & 85.97 & 85.73 & 85.95 & 6.52 & 6.81 & 7.10 & 6.81 \\
\hline Mean & 35.18 & 35.48 & 35.84 & 35.50 & 86.36 & 86.13 & 85.91 & 86.13 & 6.37 & 6.64 & 6.90 & 6.63 \\
\hline \multicolumn{4}{|l|}{ L.S.D. 0.05 Sunflower plant spacing } & N.S. & & & & N.S. & & & & N.S. \\
\hline \multicolumn{4}{|c|}{ L.S.D. 0.05 Slow - release $\mathrm{N}$ fertilizer } & 0.61 & & & & 0.42 & & & & 0.48 \\
\hline \multicolumn{4}{|l|}{ Sole sunflower } & 34.81 & & & & 86.49 & & & & 6.25 \\
\hline
\end{tabular}

\subsubsection{Response of Sunflower Plant Spacing to Slow- Release N Fertilizer}

Quality of sunflower seeds (seed oil content, total unsaturated and saturated fatty acids) was not affected significantly by sunflower plant spacing $\mathrm{x}$ slow-release $\mathrm{N}$ fertilizer rates of sunflower in the combined data across 2014 and 2015 seasons (Table 5). These data show that each of these factors act independently on all quality traits of sunflower seeds meaning that sunflower plant spacing responded similarly $(P>0.05)$ to slow-release $\mathrm{N}$ fertilizer rates of sunflower for seed oil content, total unsaturated and saturated fatty acids.

\subsection{Land Equivalent Ratio (LER)}

\subsubsection{Effect of Sunflower Plant Spacing}

LER greater than one is indicator of more efficient utilization of land in intercropping system. It is due to more efficient utilization of resources in intercropping or by increased plant density [37]. LER was affected significantly by sunflower plant spacing in the combined data across 2014 and 2015 seasons (Figure 2). In general, intercropping soybean with sunflower increased $(P \leq 0.05)$ LER compared to sole crops. It ranged from 0.94 by intercropping soybean with sunflower plants that spaced at $40 \mathrm{~cm}$ between hills $(50 \%$ soybean $+50 \%$ sunflower) with the application of $\mathrm{UF}_{2}$ to 1.25 by intercropping soybean with sunflower that spaced at $20 \mathrm{~cm}$ between hills (50\% soybean $+100 \%$ sunflower) with the application of $\mathrm{UF}_{0}$.

As a consequence of competitive effects observed in both species, intercrops were more efficient than pure crops in using resources for growth. Intercropping soybean with sunflower plants that spaced at $20 \mathrm{~cm}$ between hills $(50 \%$ soybean $+100 \%$ sunflower) had higher LER than those intercropped with sunflower plants that spaced at 30 or $40 \mathrm{~cm}$ These results reveal that the advantage of the highest LER by intercropping soybean with sunflower over sole crops could be due to the highest plant density of soybean and sunflower per unit area which formed $50 \%$ of sole soybean and $100 \%$ of sole sunflower. These results are in harmony with those obtained by Metwally et al. [29] who noticed that intercropping soybean with sunflower increased land-use efficiency. Also, Echarte et al. [38] reported higher yields for sunflower-soybean intercrops in comparison to sole crops.

\subsubsection{Effect of Slow-Release N Fertilizer}

LER was affected significantly by slow - release $\mathrm{N}$ fertilizer rates of sunflower in the combined data across 2014 and 2015 seasons (Figure 2). Sunflower plants with the application of $\mathrm{UF}_{0}$ or $\mathrm{UF}_{1}$ had higher LER than those with the application of $\mathrm{UF}_{2}$. These results may be due to the application of $\mathrm{UF}_{1}$ reached the same significance level of $\mathrm{UF}_{0}$ because $\mathrm{UF}_{1}$ provided a constant supply of $\mathrm{N}$ to roots of sunflower plants under sandy soil conditions. These results are in agreement with those observed by Metwally et al. [29] who found that LER was increased with increasing $\mathrm{N}$ fertilizer levels.

\subsubsection{Response of Sunflower Plant Spacing to Slow - Release N Fertilizer}

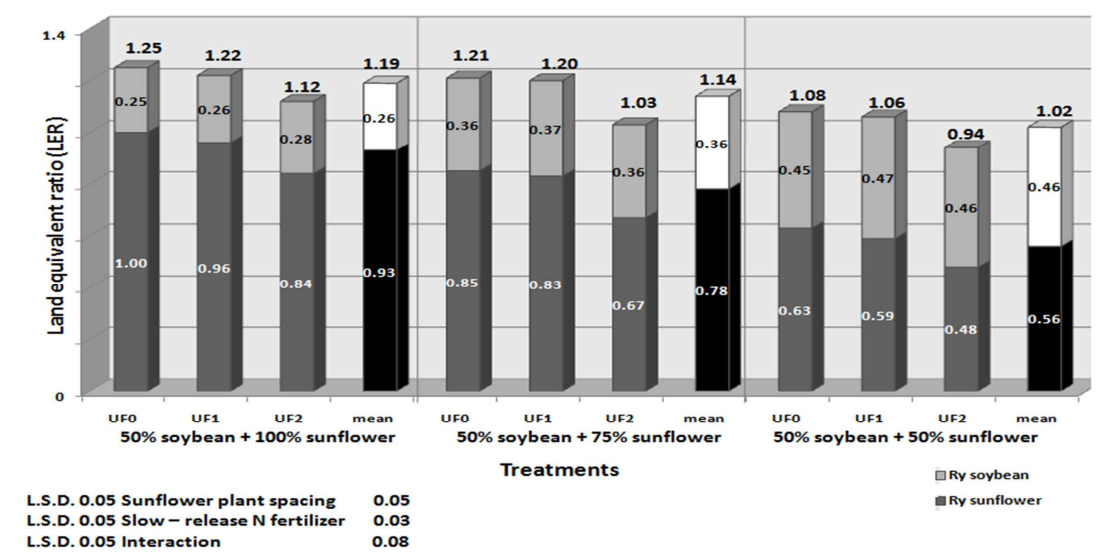

Figure 2. Land equivalent ratio (LER) as affected by sunflower plant spacing, slow - release N fertilizer and their interaction, combined data across 2014 and 2015 seasons. 
LER was affected significantly by sunflower plant spacing $\mathrm{x}$ slow - release $\mathrm{N}$ fertilizer rates of sunflower in the combined data across 2014 and 2015 seasons (Figure 2). The lowest LER was obtained by intercropping 50\% soybean with $50 \%$ sunflower that received $\mathrm{UF}_{2}$, meanwhile, the highest LER was obtained by intercropping 50\% soybean with $100 \%$ sunflower that received $U_{0}$ or $U_{1}$. These data show that each of these factors act dependently on LER meaning that sunflower plant spacing responded differently $(P \leq 0.05)$ to slow - release $\mathrm{N}$ fertilizer rates of sunflower for LER.

\subsection{Farmer's Benefit}

Intercropping compatible crop species stabilizes returns over seasons since more than one commodity is derived from the system and the components can compensate for each other in case of price fluctuation in any of the components [39]. The financial returns of intercropped sunflower with soybean as compared to sole sunflower are shown in Table
(6). Intercropping soybean with sunflower increased total and net returns compared to sole sunflower. Net returns of intercropped sunflower varied between treatments from US\$ 716 to 1094 per ha compared to sole sunflower (US\$ 695/ha). Intercropping soybean with sunflower gave the highest financial value by intercropping soybean with sunflower that spaced at $20 \mathrm{~cm}$ between hills $(50 \%$ soybean + $100 \%$ sunflower) with the application of $U_{1}$. These results indicate that growing soybean with sunflower that spaced at $20 \mathrm{~cm}$ between hills $(50 \%$ soybean $+100 \%$ wheat $)$ with the application of $\mathrm{UF}_{1}$ is more profitable to farmers than sole sunflower that received the recommended mineral $\mathrm{N}$ fertilizer rate $(142.8 \mathrm{~kg} \mathrm{~N} / \mathrm{ha})$ for Egyptian farmers. These results are in parallel with those obtained by Metwally et al. [29] who found that the highest total income was obtained with the 4 soybean: 2 sunflower system compared to sole sunflower, especially sunflower-soybean intercrop tended to be more productive than sole crops of its component species [8].

Table 6. Total and net returns as affected by sunflower plant spacing, slow - release $N$ fertilizer and their interaction, combined data across 2014 and 2015 seasons.

\begin{tabular}{|c|c|c|c|c|c|c|c|c|c|c|c|c|c|c|c|c|}
\hline \multirow{2}{*}{ Treatments } & \multicolumn{4}{|c|}{ Sunflower } & \multicolumn{4}{|c|}{ Soybean } & \multicolumn{4}{|c|}{ Total } & \multicolumn{4}{|l|}{ Net } \\
\hline & $\mathbf{U F}_{\mathbf{0}}$ & $\mathbf{U F}_{1}$ & $\mathbf{U F}_{2}$ & Mean & $\mathbf{U F}_{\mathbf{0}}$ & $\mathbf{U F}_{1}$ & $\mathbf{U F}_{2}$ & Mean & $\mathbf{U F}_{\mathbf{0}}$ & $\mathbf{U F}_{1}$ & $\mathbf{U F}_{2}$ & Mean & $\mathbf{U F}_{\mathbf{0}}$ & $\mathbf{U F}_{1}$ & $\mathbf{U F}_{2}$ & Mean \\
\hline $50 \%$ soy $+100 \%$ sunflower & 1595 & 1540 & 1347 & 1494 & 493 & 535 & 535 & 521 & 2088 & 2075 & 1882 & 2015 & 1073 & 1094 & 935 & 1034 \\
\hline $50 \%$ soy $+75 \%$ sunflower & 1352 & 1327 & 1065 & 1248 & 691 & 709 & 679 & 693 & 2043 & 2036 & 1744 & 1941 & 1052 & 1079 & 821 & 984 \\
\hline $50 \%$ soy $+50 \%$ sunflower & 1000 & 936 & 762 & 899 & 841 & 878 & 866 & 861 & 1841 & 1814 & 1628 & 1761 & 861 & 868 & 716 & 815 \\
\hline Mean & 1315 & 1267 & 1058 & 1213 & 675 & 707 & 693 & 691 & 1990 & 1975 & 1751 & 1905 & 995 & 1013 & 824 & 944 \\
\hline Sole sunflower & \multicolumn{4}{|c|}{1590} & \multicolumn{4}{|c|}{---} & & & & 1590 & \multicolumn{4}{|c|}{695} \\
\hline
\end{tabular}

Prices of main products are that of 2013: US\$ 495.4 for ton of sunflower; US\$ 601.4 for ton of soybean; intercropping soybean with sunflower increased variable costs of intercropping culture from US\$120 - 339 per ha over those of sole sunflower.

\section{Conclusion}

Our results revealed that growing sunflower as one plant/hill spaced at $20 \mathrm{~cm}$ in both sides of ridge $120 \mathrm{~cm}$ width with growing two rows of soybean in middle of the ridge $(50 \%$ soybean $+100 \%$ sunflower) could be economically and environmentally promising in the newly reclaimed soils by using $107.1 \mathrm{Kg} \mathrm{N} / \mathrm{ha}$ as urea form of slow - release N. This treatment yielded 1.29 ton of edible oil per ha and decreased $25 \%$ of the recommended mineral $\mathrm{N}$ fertilizer rate of sunflower with good quality of sunflower seeds.

\section{References}

[1] Ahmad R, Hussain N, Mahmood T and Amjad M. 1992. Growth and yield performance of some sunflower (Helianthus annuus L.) hybrids planted in spring season. Pak. J. Agric. Sci., 29 (3): $288-291$.

[2] Demir AO, Goksoy AT, Buyukcangaz H, Turan ZM and Koksal ES. 2006. Deficit irrigation of sunflower (Helianthus annuus L.) in a sub-humid climate. Irrigation Sci., 24: 279 - 289.

[3] FAO. 2010. Statistical Year Book, World food and agriculture. Food and Agriculture Organization of the United Nations, Rome.
[4] FAO. 2013. Statistical Year Book, World food and agriculture. Food and Agriculture Organization of the United Nations, Rome.

[5] Vandermeer J. 1989. The Ecology of Intercropping. Cambridge Univ. Press, Cambridge, UK. 254p.

[6] Chowdhury MK and Rosario EL. 1992. Utilization efficiency of applied nitrogen as relayed to yield advantage in maize/mungbean intercropping. Field Crops Res., 30: 41 - 51.

[7] Calviño P and Monzon JP. 2009. Farming systems of Argentina: Yield constrains and risk management. In: Sadras $\mathrm{V}$ and Calderini D, editors, Crop physiology. Applications for genetic improvement and agronomy. Academic Press, Amsterdam. p. $55-70$.

[8] Andrade JF, Cerrudo A, Rizzalli RH and Monzon JP. 2012. Sunflower-soybean intercrop productivity under different water conditions and sowing managements. Agron. J., 104 (4): $1049-1055$.

[9] Coll L, Cerrudo A, Rizzalli RH, Monzon JP and Andrade FH. 2012. Capture and use of water and radiation in summer intercrops in the southeast Pampas of Argentina. Field Crops Res.,134: $105-113$.

[10] Sûzer S and Atakisi I. 1993. Yield components of sunflower hybrids of different height. HELA, 16 (18): 35 - 40. 
[11] Zarea MJ, Ghalavand A and Daneshian J. 2005. Effect of planting patterns of sunflower on yield and extinction coefficient. Agron. Sustain. Dev., 25: 513-518.

[12] Akunda EM. 2001. Inter cropping and population density effects on yield component, seed quality and photosynthesis of sorghum and soybean. J. Food Techno. in Africa, 6 (3): $96-$ 103 .

[13] Abdel-Galil AM, Abdel-Wahab ShI and Abdel-Wahab TI. 2014b. Compatibility of some maize and soybean varieties for intercropping under sandy soil conditions. Proc. $1^{\text {st }}$ Conf. of Int. Soybean Res., Indore, 22 - 24 February, India.

[14] Scheiner JD, Gutie'rrez-Boem FH and Lavado RS. 2002. Sunflower nitrogen requirement and $15^{\mathrm{N}}$ fertilizer recovery in Western Pampas, Argentina. Eur. J. Agron., 17: 73-79.

[15] Ali A and Ullah S. 2012. Effect of nitrogen on achene protein, oil, fatty acid profile, and yield of sunflower hybrids. Chilean J. Agric. Res., 72 (4): 564 - 567.

[16] Nasim W, Ahmad A, Bano A, Olatinwo R, Usman M, Khaliq T, Wajid A, Hammad HM, Mubeen M and Hussain M. 2012. Effect of nitrogen on yield and oil quality of sunflower (Helianthus annuus L.) hybrids under sub humid conditions of Pakistan. American J. Plant Sci., 3: 243 - 251.

[17] Chapman HD and Pratt PE. 1961. Methods of Analysis for Soil, Plant and Water. Division Agric. Sci., California Univ., U.S.A.

[18] Clipson, NJW, Edwards SJ, Hall JF, Leach CK, Rayns FW and Weston GD. 1994. Crop Productivity. Published on Behalf of: Open Univ. and Univ. Greenwish (Formerly Thames Polytechnic), Avery Hill Road, Eltham, London SE92HB, 5 p.

[19] A.O.A.C. 2000. Association of Official Agricultural Chemists Official Methods of Analysis. $15^{\text {th }}$ A. O. A. C., Washington, USA.

[20] Sadasivam S and Manickam A. 1997. Biochemical Methods. $2^{\text {nd }}$ edn. New age international (p) Ltd. Publisher, New Delhi, $5-207$.

[21] Vogel AJ. 1975. A Text Book of Practical Organic Chemistry. English Language Book Society And Longman Group Ltd. London, 3th ed., pp. $969-971$.

[22] Farag RS, Hallabo SAS, Hewedi FM and Basyony AE. 1981. Chemical evaluation of rape seed. Fette Seifen Anstrichmittel, 88 (10): $391-397$.

[23] Mead R and Willey RW. 1980. The concept of a "land equivalent ratio" and advantages in yields from intercropping. Experimental Agric., 16: $217-28$.

[24] Bulletin of Statistical Cost Production and Net Return. 2014. Summer and Nili Field Crops and Vegetables and Fruit, Agriculture Statistics and Economic Sector, Ministry of Egyptian Agriculture and Land Reclamation, Part (2), August 2014.

[25] Freed RD. 1991. MSTATC Microcomputer Statistical Program. Michigan State University, East Lansing, Michigan, USA.
[26] Gomez KA and Gomez AA. 1984. Statistical Procedures for Agricultural Research. 2nd ed., John Willey and Sons, Toronto, ON, Canada.

[27] Chang JH. 1974. Radiation balance. Climatic and Agriculture. An ecological survey, pp. 4 -22. Aldine Publishing Company, Chicago, Illinois, USA.

[28] Gadallah RA, Badr MMA and Abdel-Galil AM. 2006. Effect of intercropping patterns and plant distribution of sunflower with soybean on growth, yield and yield components of soybean and sunflower. Minufiya J. Agric. Res., 31 (4): $915-$ 938.

[29] Metwally IO, Ibrahim EM and Abdel-Galil AM. 2008. Response of some intercropping systems of soybean with sunflower to organic and mineral fertilization. Proc. $2^{\text {nd }}$ Field Crops Conf., 14 - 16 October, FCRI, ARC, pp. 419 433.

[30] Metwally AA, Shafik MM, El-Habbak KE and Abdel-Wahab ShI. 2012. Yield and soybean characters under some intercropping patterns with corn. Soybean Res., 10: $24-42$.

[31] Abdel-Galil AM, Abdel-Wahab TI and Abdel-Wahab ShI. 2014a. Productivity of four soybean varieties as affected by intercropping and corn planting geometry. Soybean Res., 12 (1): $36-58$.

[32] Sûzer S. 2010. Effects of nitrogen and plant density on dwarf sunflower hybrids. HELIA, 33 (53): 207 - 214.

[33] Ahmed KhA. 1993. Evaluation of efficiency of some N-slowrelease fertilizers under different rates of phosphatic fertilizers. Ph. D. Thesis, Fac. Agric., Moshtohour, Benha Branch, Zagazig Univ., Egypt.

[34] Bungard RA, Wingler A, Morton JD and Andrews M. 1999. Ammonium can stimulate nitrate and nitrite reductase in the absence of nitrate in Clematis vitalba . Plant Cell Env., 22: 859-866.

[35] Al-Thabet SS. 2006. Effect of plant spacing and nitrogen levels on growth and yield of sunflower (Helianthus annuus, L.) J. King Saud Univ., Agric. Sci., 19 (1): 1-11, Riyadh.

[36] Ibrahim ME, EL-Ghany HMA and Gaafar NA. 2006. Effect of nitrogen fertilizer and its application time on growth and yield of two sunflower varieties. Bulletin of the National Res. Center (Cairo). 31: 3, $233-243$.

[37] Fisher NM. 1977. Studies in mixed cropping. Exp. Agric., 13: $169-177$.

[38] Echarte L, Maggiora AD, Cerrudo D, Gonzales VH, Abbate P, Cerrudo A, Sadras VO and Calviño P. 2011. Yield response to plant density of maize and sunflower intercropped with soybean. Field Crops Res., 121: 423 - 429.

[39] Osiru DSO. 1982. Intercropping: A review of possible advantages. In Proc. the Indian Statistical Inst. Golden Jubilee Int. Conf. Frontiers of Res. Agric. (S.K. Roy ed.), pp. $304-$ 320. Calcutta, September 27 - October 1, 1982. 